\title{
Дослідження засобів створення обчислювального кластера на основі технологій віртуалізації
}

Проведено аналіз сучасних технологій створення обчислювальних кластерів. Розглянуто питання налаштування та установлення систем OpenVZ, HyperVM, Hyper-V. Розглянуто етапи налаштування OрепVZ для OC Ubuntu/Debian. Розглянуто особливості налаштування систем при вирішенні завдань віртуалізації. Розглянуто особливості НурегVМ як розповсюдженої технології для управління фермою фізичних і віртуальних серверів, використовуючи веб-орієнтований інтерфейс. Розглянуто можливості використання НурегVM на основі управління сертифікатами, протоколами віддаленого доступу, визначення списків сервісів і процесів та побудови звітів з роботи віртуальних машин. Розглянуто питання побудови обчислювального кластера на основі операційної системи Lіпих на базі системи Hуреr-V.

Ключові слова: віртуалізачія, операційна система, обчислювальний кластер, сервер, віртуальна машина, комп'ютерна мережа.

\begin{abstract}
Вступ
Розвиток сучасних інформаційно-комунікаційних технологій передбачає впровадження засобів віртуалізації, наприклад, в хмарних обчисленнях, які базуються на вирішенні широкого класу задач планування, розподілу ресурсів віртуалізованих засобів зберігання та обробки даних в розподілених системах $[1,2]$.

Ринок рішень віртуалізації для побудови кластерних обчислювальних систем досить великий, отже вибір певного рішення визначається витратами на його придбання, обслуговування та кількістю наданих клієнтам інструментів управління віртуальними серверами (вузлами). В даній роботі аналіз віртуальних кластерних рішень здійснено на основі існуючих у теперішній час безкоштовних продуктів. В результаті проведеного аналізу обрано три системи: OpenVZ, HyperVM, Hyper-V [3 - 7].
\end{abstract}

\section{Основна частина дослідження \\ 1. Аналіз рішень щодо технологій віртуалізації обчислювальних кластерів \\ 1.1 Система OpenVZ \\ Найпростішим варіантом розподілення фізичного сервера на віртуальні вузли є побудова кластера на базі використання системи OpenVZ - розширення ядра Linux, що реалізуе концепцію віртуального середовища (Virtual Environments, VE). Віртуалізація здійснюється на рівні екземплярів операційних систем (OC), при цьому одне ядро використовується для всіх VE: ядро забезпечує віртуалізацію, ізоляцію, керування ресурсами й збереження поточного стану кожного}

(C) С.В. Мінухін, В.М. Задачин, 2016 віртуального приватного сервера. Як гостьові ОС можна використати дистрибутиви Linux. B OpenVZ підтримується до 4096 процесорів i до 64 Гб оперативної пам'яті. Всі процеси розділені й повністю ізольовані один від одного, при цьому кожний виконується у своєму адресному просторі, віртуальний мережний пристрій (venet) використовує свою IPадресу. Клієнт одержує будь-яку кількість виділених віртуальних серверів зі своїми додатками, які зовні виглядають як окремі сервери, але побудовані на основі однієї апаратної платформи.

Налаштування та установлення OpenVZ для OC Ubuntu/Debian виконується аналогічно OC CentOS. Основна система повинна бути 64-бітною, тому що в цьому випадку є можливість використання 64-бітних шаблонів ОС. Ряд обмежень 32-бітних ОС (наприклад, максимальний обсяг ОП - 4 Гб) лімітує кількість серверів і можливості подальшого їх розширення. В документації Ubuntu рекомендується використовувати для зберігання образів віртуальних машин систему управління дисковим простором LVM, що дозволяе виконувати процедуру резервного копіювання 3 нульовим часом простою (Zero Downtime Backup) i уникнути проблем при підключенні нових дисків.

Налаштування цієї системи здійснюється на основі наступних етапів.

Етап 1. Відключається система захисту SELinux або AppArmor. Поточний стан перевіряється такими командами:

\$ dmesg | grep SELinux

SELinux: Disabled at boot.

\$ dmesg | grep -i AppArmor

AppArmor: AppArmor initialized

AppArmor: AppArmor Filesystem Enabled. 
Далі припиняється робота програми AppArmor:

\$ sudo/etc/init.d/apparmor stop

\$ sudo update-rc.d -f apparmor remove

\$ sudo apt-get remove apparmor apparmor-utils.

Етап 2. Відключається SELinux шляхом визначення параметра "selinux=0" у параметрах ядра у налаштуваннях завантажника menu.lst: "kernel .... selinux=0" або в /etc/sysconfig/selinux установкою "selinux=disabled".

Ядро Ubuntu, що використовується за замовчуванням, не підтримує OpenVZ, але в офіційному репозитарії вже є для цього все необхідне. Крім того, можна використовувати останню версію ядра зі сайта OpenVZ і зібрати ядро самостійно. Розроблювачі OpenVZ пропонують RPM пакети для RHEL i репозитарій для Ubuntu 8.04 LTS. Для його підключення у файл /etc/apt/sources.list треба додати рядок:

deb http://download.openvz.org/ubuntu hardy experimental.

Етап 3. Оновлюється список пакетів:

\$ sudo apt-get update

\$ sudo apt-cache search openvz.

Останне ядро ставиться разом 3 утилітами управління:

\$ sudo apt-get install linux-openvz vzctl vzquota.

Етап 4. Змінюються системні налаштування шляхом модифікації файлу /etc/sysctl.conf таким чином:

\$ sudo nano /etc/sysctl.conf
\# Умикаємо форвардинг, відключається ARP проксі:

net.ipv4.conf.default.forwarding $=1$

net.ipv4.conf.default.proxy_arp=1

net.ipv4.ip_forward $=1$

net.ipv4.conf.all.rp_filter $=1$

net.ipv4.conf.default.send_redirects $=1$

net.ipv4.conf.all.send_redirects $=0$

\# Умикаємо SysRq клавіші

kernel. sysrq $=1$.

Зберігаємо зміни й застосовуємо їх:

\$ sudo sysctl - p.

Якщо віртуальні VM будуть використовувати діапазон IP-адрес, який відрізняється від реальної системи, то в конфігурації OpenVZ параметра NEIGHBOUR_DEVS присвоюється значення all:

\$ sudo nano /etc/vz/vz.conf

NEIGHBOUR_DEVS=all.

Етап 5. Перевіряється наявність запису щодо нового ядра в конфігурації завантажника (він вноситься автоматично при встановленні пакета) за допомогою команди:

\$ grep openvz /boot/grub/menu.lst.

Етап 6. Створюється символічне посилання:

\$ sudo $\ln$-s /var/lib/vz /vz.

Етап 7. Після перезавантаження 3 новим ядром /vz/template/cache шаблони операційних систем, які будуть використовуватися для віртуалізації, скачуються в каталог (рис. 1) (наприклад, Ubuntu):

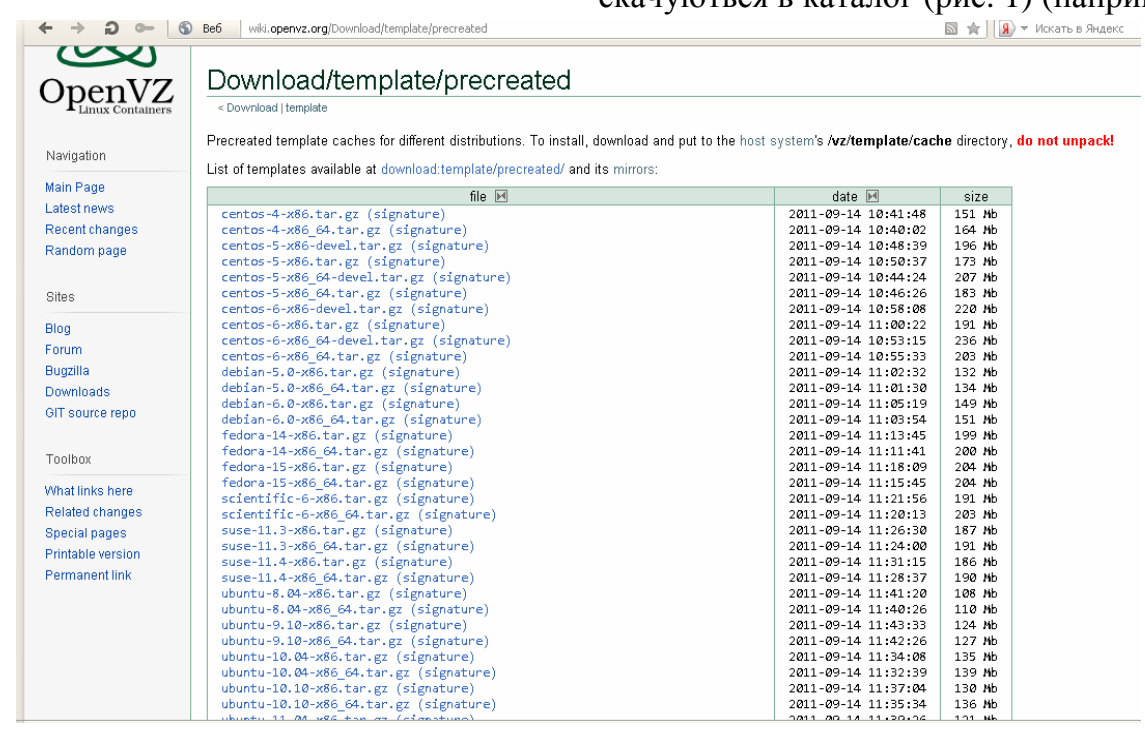

Рис. 1. Шаблони ОС 
\$ wget -c http://download.openvz.org/template/ precreated/contrib/ubuntu-8.04.2-i386-minimal.tar.gz

$\$$ sudo cp -v ubuntu-8.04.2-i386-minimal.tar.gz /vz/template/cache

При масовому розгортанні рекомендується локалізувати VM у контейнері, 3 якого й створити новий шаблон.

\section{2 Система HyperVM}

HyperVM є досить розповсюдженою технологією для управління фермою як фізичних, так і віртуальних серверів (VPS/VDS), використовуючи інтерфейс, що побудований на основі веб-технологій. У теперішній час підтримуються дві технології віртуалізації OpenVZ й Xen. Для зручності конфігурування застосовуються системи планування використання ресурсів (Resource Plan), у яких наводяться такі установки: кількість VPS, дискова квота, гарантована OП, трафік. Інтерфейс є єдиним як для Xen, так і для OpenVZ, більша частина параметрів стосується обох технологій, однак зустрічаються налаштування "OpenVZ Only" та "Xen Only".

Серед додаткових можливостей панелі HyperVM слід відзначити управління сертифікатами, протокол віддаленого доступу SSH, визначення списків сервісів і процесів 3 можливістю зупиняти будь-які 3 них, побудову звітів 3 роботи віртуальних машин. Для швидких комунікаційних каналів можна активувати підтримку Ајах. Для гарантування безпеки пропонується обирати діапазони дозволених IP-адрес, 3 яких можна підключатися до панелі і блокувати IP. При установленні підтримуються тільки RHEL дистрибутиви (рекомендується CentOS).

Установлення виконується на основі скрипта, який відправляється на виконання (у ролі параметра virtualization-type вказується тип віртуалізації - в даному випадку xen/openvz/NONE):

\$ wget -c

http://download.lxcenter.org/download/hypervm/productio n/hypervm-install-master.sh

$\$$ sudo sh ./hypervm-install-master.sh -ivirtualizationtype $=$ openvz.

Якщо планується розгорнути цілий кластер, то інструкція hypervm-install-master.sh виконується на сервері, в інших випадках - використовується інструкція hypervm-install-slave.sh.

\section{3 Система Hyper-V}

Hyper-V є віртуальним середовищем, що працює безпосередньо на апаратному рівні. Архітектура Hyper$\mathrm{V}$ складається 3 гіпервізора мікроядра, а також батьківських і дочірніх розділів. Всі версії Hyper-V мають один батьківський розділ, що управляє функціями Hyper-V. 3 батьківського розділу запускається консоль Windows Server Virtualization. Крім того, батьківський розділ використовується для запуску віртуальних машин (VM), що підтримують потокову емуляцію старих апаратних засобів. Гостьові VM запускаються $з$ дочірніх розділів Hyper-V. Дочірні розділи підтримують два типи VM: високопродуктивні VM на основі архітектури VMBus та VM, що управляються системою-вузлом. До першої групи входять VM із системами Windows Server 2003, Windows Vista, Windows Server 2008 й Linux, які підтримують Xen. Нову архітектуру VMBus відрізняє високопродуктивний конвеєр, що функціонує в оперативній пам'яті та з'єднує клієнтів Virtualization Service Clients (VSC) на гостьових VM 3 провайдером Virtual Service Provider (VSP) вузла. Слід зазначити, що Hyper-V працює тільки на 64-розрядних процесорах, які підтримують технології Intel VT або AMD-V (Pacifica). При цьому в BIOS повинен бути активізований механізм захисту коду (Intel XD або AMD NX).

До основних можливостей Hyper-V слід віднести:

- підтримку як процесорних, так i багатопроцесорних віртуальних машин 3 максимальною кількістю процесорів 24;

- наявність фізичного сервера (об'єм - до 1 Тб оперативної пам'яті, для віртуальних машин підтримка 128 Гб оперативної пам'яті);

- можливість одночасного запуску до 192 віртуальних машин, кількість налаштованих, але не працюючих VM, обмежено 512;

- одночасну роботу 32- та 64-бітних версій гостьових ОС;

- підтримку у віртуальних локальних мережах (VLAN) до 4096 пристроїв;

- наявність до 12 віртуальних мережних адаптерів; 2 Тб);

- наявність чотирьох віртуальних дисків (до

- можливість створення миттєвих знімків працюючих віртуальних машин. У таку копію записується також системний стан, дані й конфігурація апаратних засобів.

Для локального й видаленого управління Hyper-V використовуються утиліти (наприклад, комплект "Hyper-V Tools") або диспетчер Hyper-V (Hyper-V Manager). Останній може встановлюватися на іншому комп'ютері, що працює під керуванням Windows 2003 i вищих версій. При цьому сервер можна розгорнути, як у повному варіанті, так й у скороченому (Server Core). Для Windows 7 інструмент включений до комплекту Remote Server Administration Tools for Windows 7 (RSAT), куди входить ще ряд консолей, які дозволяють налаштувати, крім Hyper-V, сервіс Active Directory, протокол призначення адрес DHCP, сервіс DNS, RDP, а також компоненти BitLocker, GPO, Network Load Balancing. 


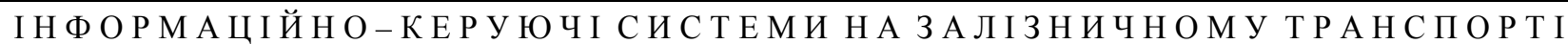

У промисловому середовищі налаштування віддаленого доступу для великої кількості користувачів є складним завданням, однак це можливо реалізувати за допомогою сценарію HVRemote (HyperV Remote Management Configuration Utility, [8]). За його допомогою можна додати або видалити обліковий запис, робочу групу й домен, відкрити потрібні порти в WF i діагностувати проблеми. Найбільш потужним рішенням $\epsilon$ диспетчер віртуальних комп'ютерів SCVMM 2008 (System Center Virtual Machine Manager, [9]), який дає можливість управляти фізичною й віртуальною інфраструктурою, причому не тільки Hyper-V, але й Microsoft Virtual Server 2005, VMware ESX/ESXi, та переносити фізичну інфраструктуру на віртуальні пристрої.
2. Побудова кластера на основі OC Linux (Centos) на базі системи Нурег-V

2.1. Вибір устаткування для віртуалізації кластера на основі системи Hyper-V

До вимог до устаткування, що обирається, слід віднести такі: всі процесори обчислювальної кластерної системи повинні мати підтримку 64-бітної шини (2008 R2 використовує тільки в 64-бітну шину); програмне забезпечення Hyper-V Server 2008 R2, яке $\epsilon$ модифікацією Windows Server 2008 R2 у режимі ядра 3 увімкненим (за замовчуванням) гіпервізором й консольним управлінням для централізованого управління (рис. 2). Цей вибір обумовлений тим, що немає необхідності витрачати ресурси хостового сервера на підтримку будь-яких інших ролей, крім гіпервізора.

http://it-bezpeka.org.ua/wp-content/uploads/2011/10/hyper-v_server_r2_screenshot.jpg

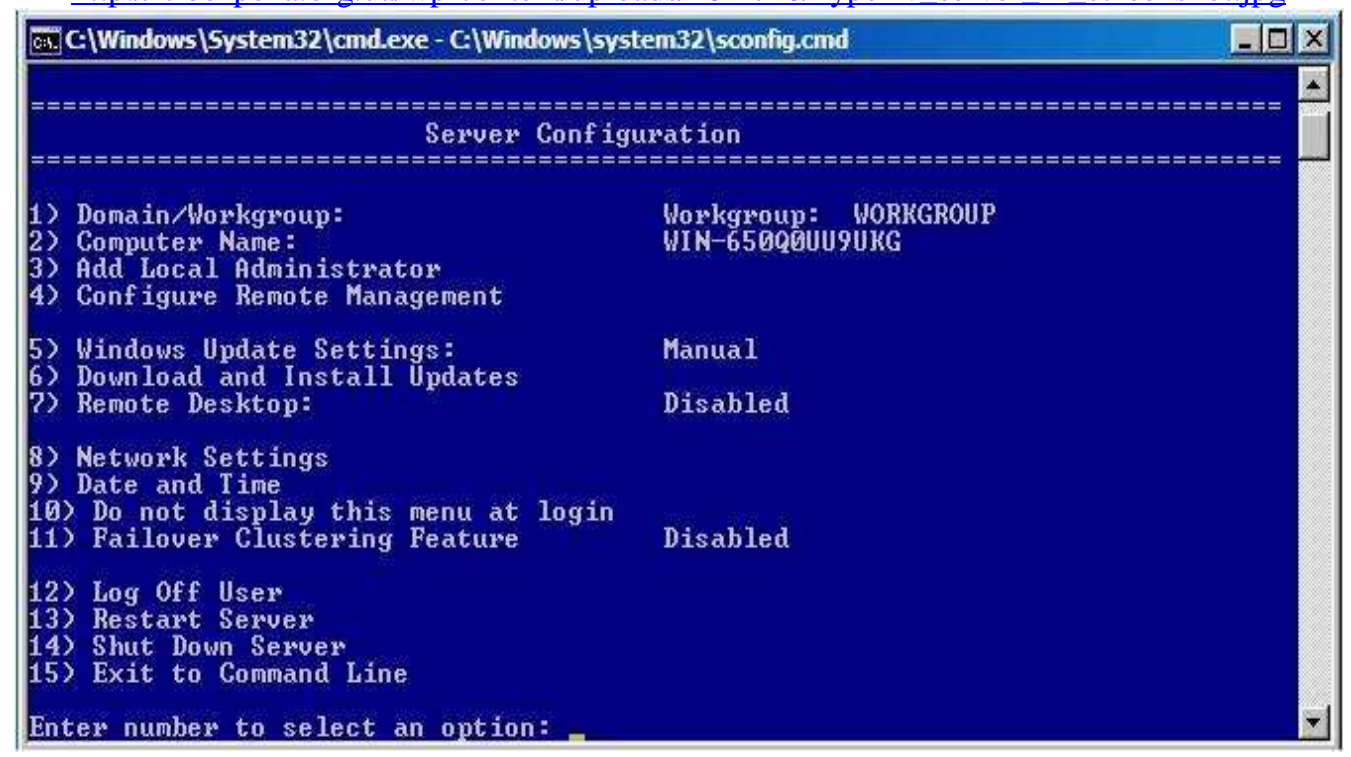

Рис. 2. Завантаження гіпервізора

При використанні цього гіпервізора потрібно ліцензувати тільки віртуальні машини, які будуть на ньому запускатися. Як сховище використовується робоча станція, на якій встановлено два жорстких диски об'ємом 250 Гб кожен, що об'єднані у масив RAID0 засобами OC. Для перебудови сервера в сховище використовується найдешевший 3 можливих варіантів - iSCSI. Ця машина буде керуючою для кластера Hyper-V, а також буде контролером домену.

Запропоноване сховище буде працювати під управлінням Windows Server 2008 R2.

\section{2. Налаштування обчислювального кластера}

Етап 1

На цьому етапі використовуються дві OC Hyper-V Server 2008 R2 та Windows Server 2008 R2.
Перед налаштуванням кластера для його коректної роботи необхідно налаштувати мережу шляхом визначення для всіх серверів локальних IP-адрес, попередньо підключивши їх до комутатора. Дозволяємо вилучений доступ до вузлів кластера через RDP та через консоль ММС. Це необхідно зробити до визначення вузлів домену. Визначається домен і підключаються до нього кластерні вузли 3 увімкненням Failover Clustering Feature.

Етап 2. Налаштування сховища

На цьому етапі RAID0 розділяється на два логічні диски - один - для File Share Witness (близько 15 Гб), другий - для зберігання віртуальних машин (рис. 3). 
http://it-bezpeka.org.ua/wp-content/uploads/2011/10/disks.png

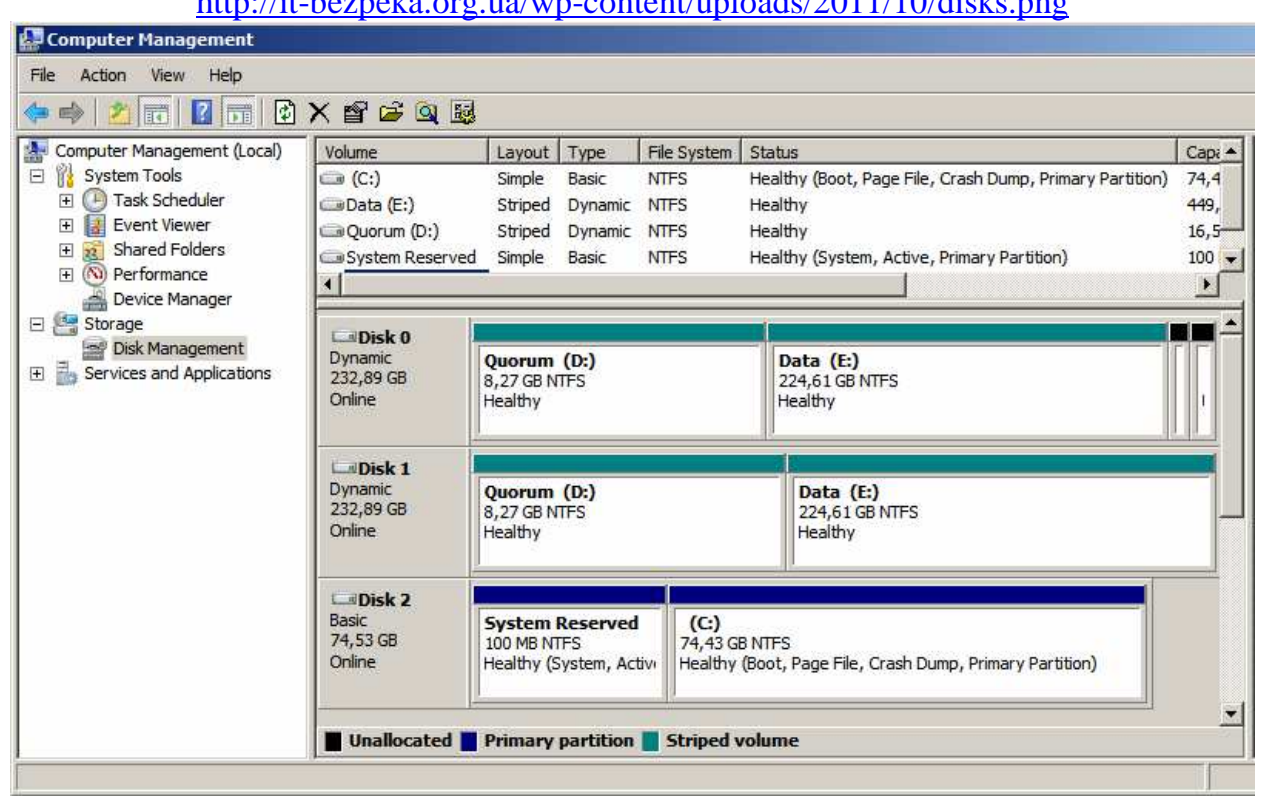

Рис. 3. Налаштування сховища для віртуальних машин

Далі встановлюється StarWind iSCSI Target, після чого треба пропустити через Windows Firewall порти 3260, 3261. Для авторизації потрібні логін і пароль, які в базовому варіанті визначені як root й starwind відповідно (рис. 4).
Після підключення до сервера необхідно вказати файл із ліцензією у вкладці Configuration серверної консолі StarWind (рис. 5).

В процесі створення таргету формуються розмічені img-файли, які відбивають роль LUN-ів (віртуальних жорстких дисків) (рис. 6).

http://it-bezpeka.org.ua/wp-content/uploads/2011/10/starwind1.png

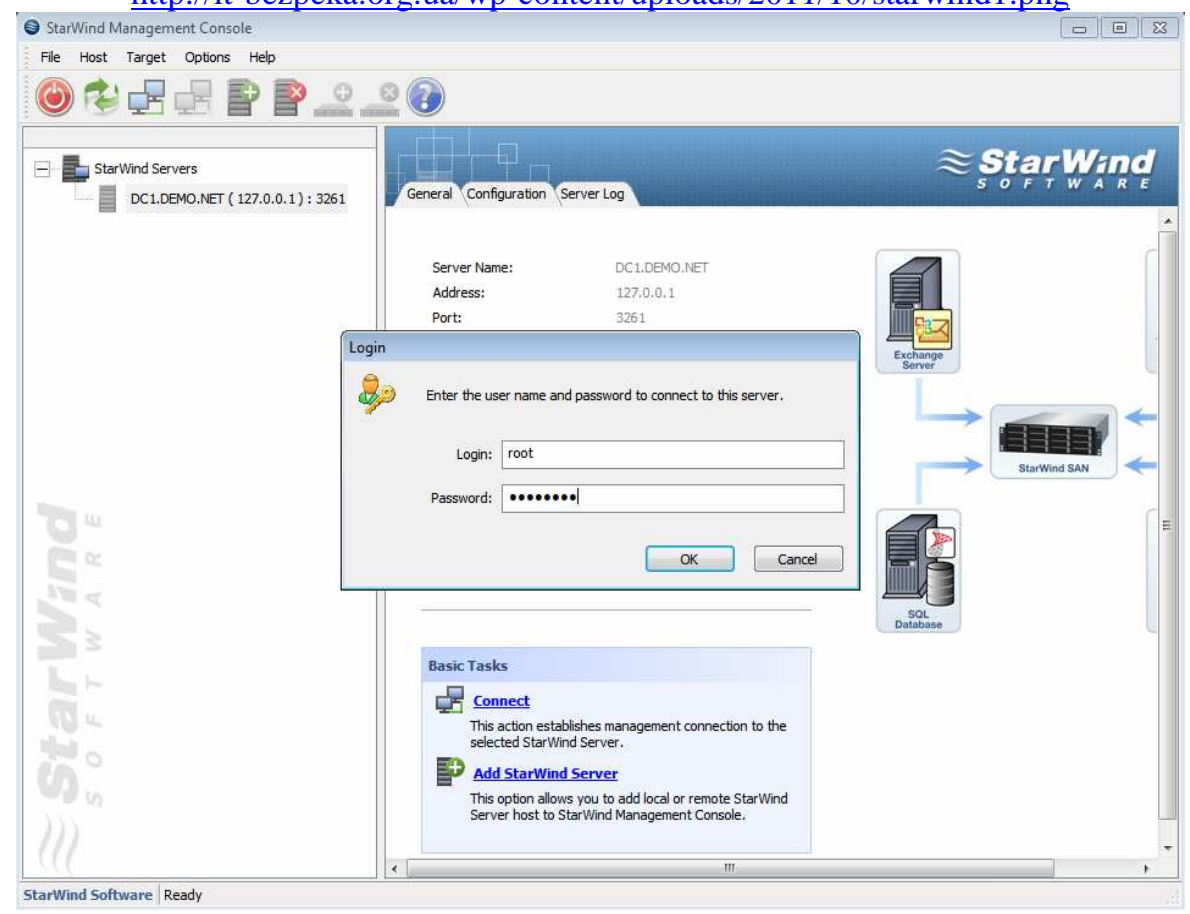

Рис. 4. Процедура авторизації 
http://it-bezpeka.org.ua/wp-content/uploads/2011/10/starwind-reg.png

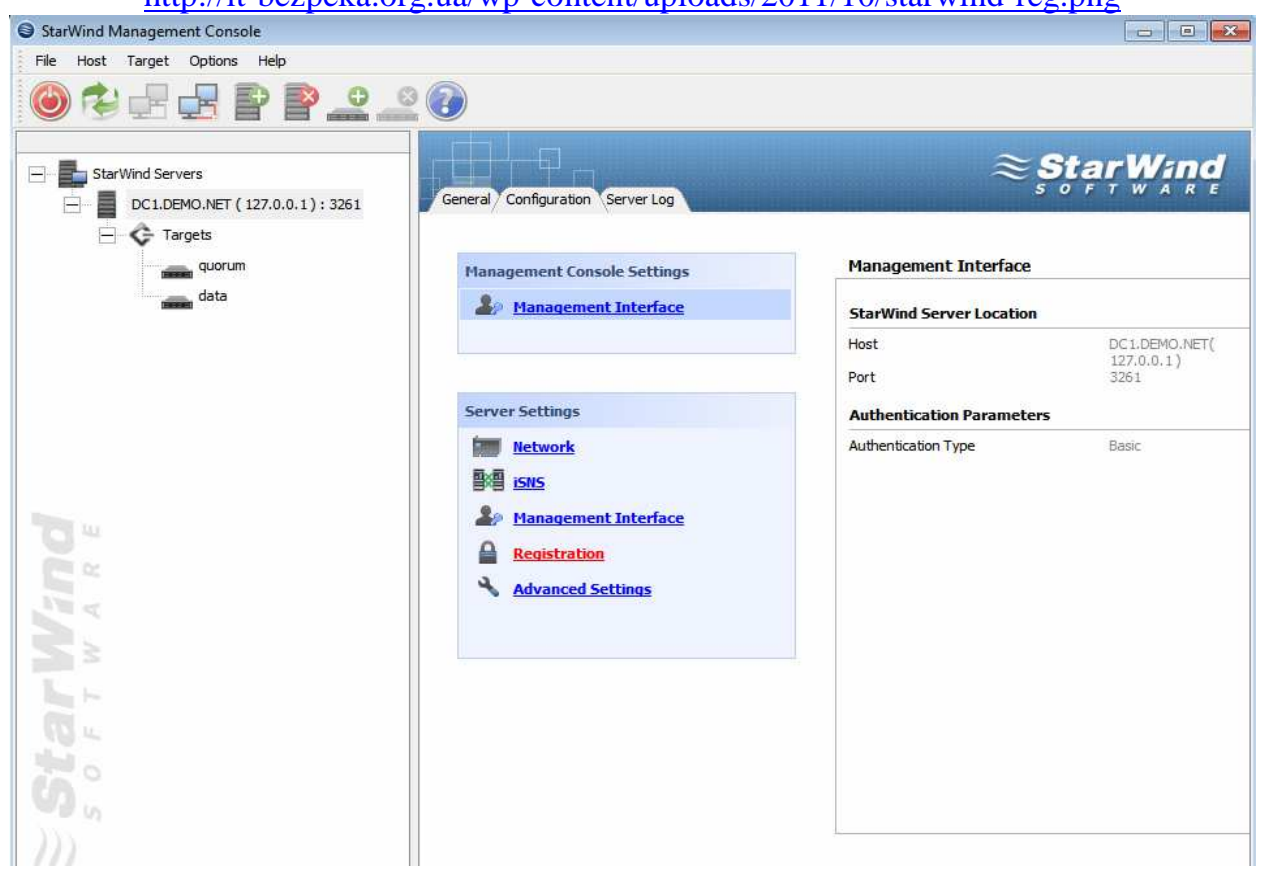

Рис. 5. Запуск серверної консолі StarWind

http://it-bezpeka.org.ua/wp-content/uploads/2011/10/starwind-target.png

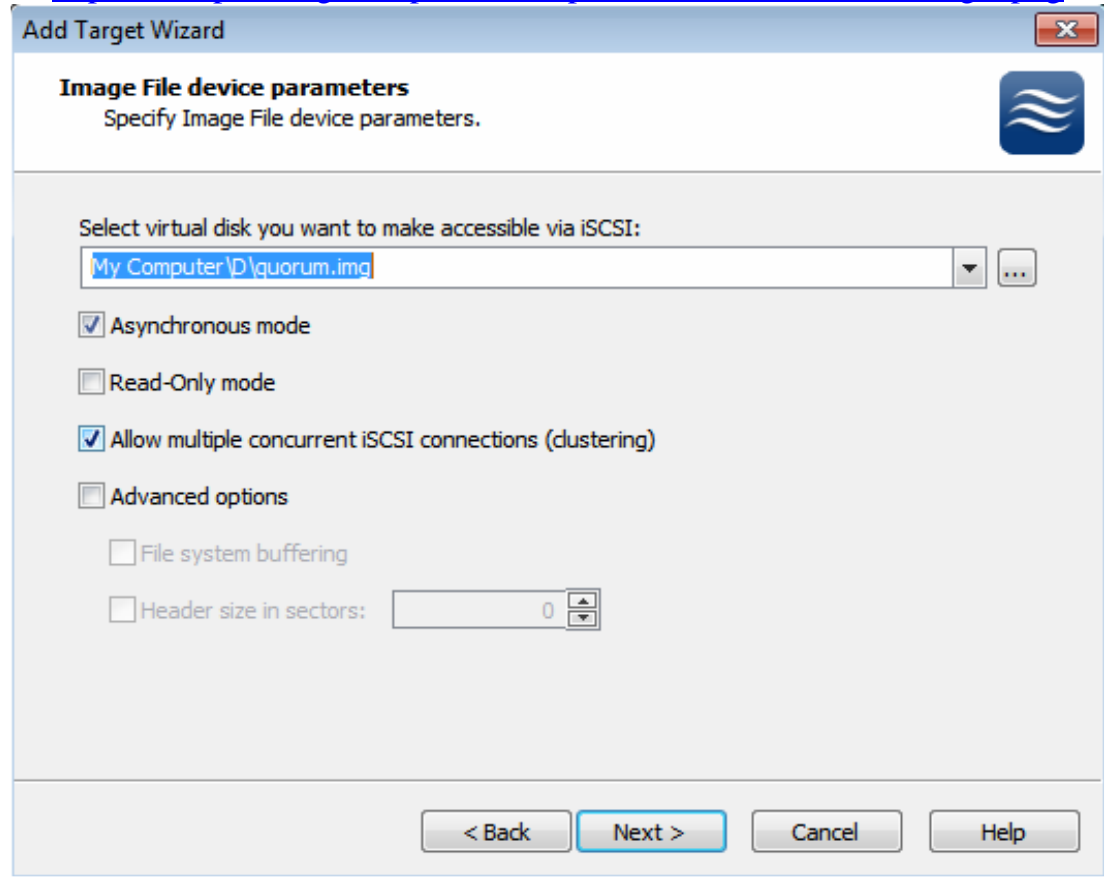

Рис. 6. Розміщення img-файлів у розділах системи

Вони розміщуються на відповідних розділах та при результаті проведених дій отримуємо архітектуру 3 цьому ставиться помітка (рис. 6), що відповідальна за двох таргетів: один під кворум, другий - під дані конкурентні з'єднання iSCSI, тобто кластеризацію. У (рис. 7). 


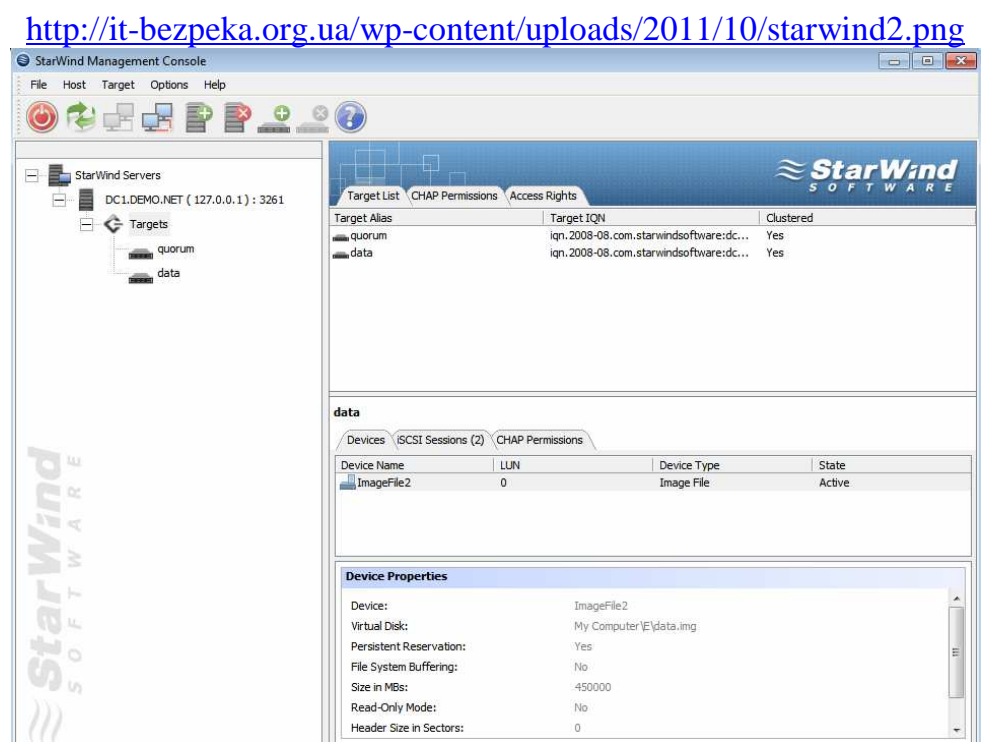

Рис. 7. Архітектура таргетів системи

Етап 3

У серверах версії 2008 R2 встановлено iSCSI Initiator, що відповідає за підключення LUN-iв до отриманого сховища у ролі локальних дисків. У зв'язку 3 відсутністю GUI на консольному Hyper-V Server його треба викликати через командний рядок або Powershell за допомогою команди iscsicpl. У полі, що підсвічене жовтим кольором, необхідно ввести IP-адресу сховища, після чого повинно з'явитися спливаюче віконце з розміщеними на сервері таргетами (рис. 8).

http://it-bezpeka.org.ua/wp-content/uploads/2011/10/iscsicapture PNG.png

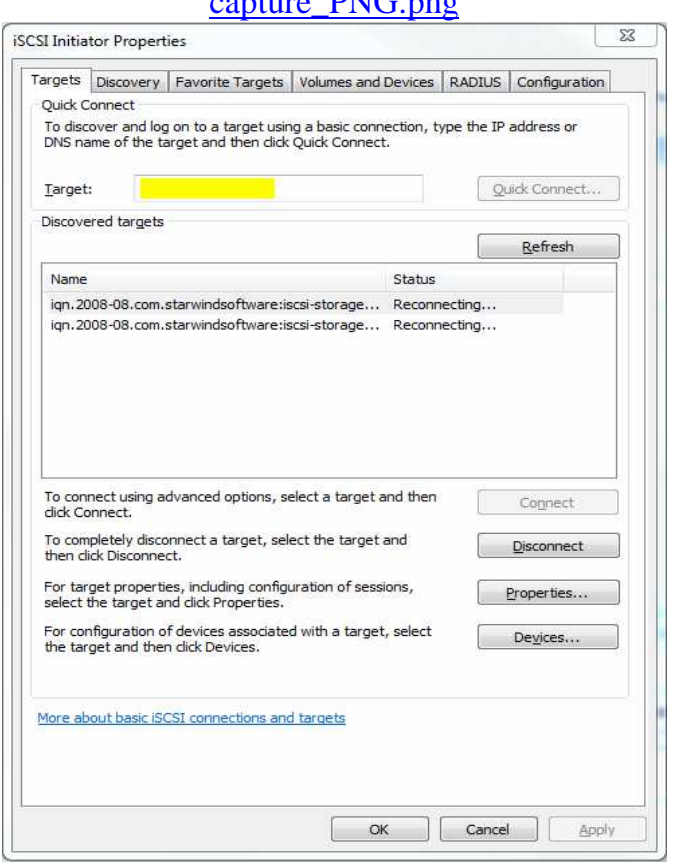

Рис. 8. Визначення IP-адреси сховища
Після того, як таргети будуть підключені до сервера, необхідно змонтувати їх як диски.

Після натискання на Autoconfigure (рис. 9) у порожньому віконці з'являться два шляхи до дисків, що визначають шлях. Після цього можна увімкнути Disk Management і визначати букви дискам.

http://it-bezpeka.org.ua/wp-content/uploads/2011/10/iscsivolume PNG.png

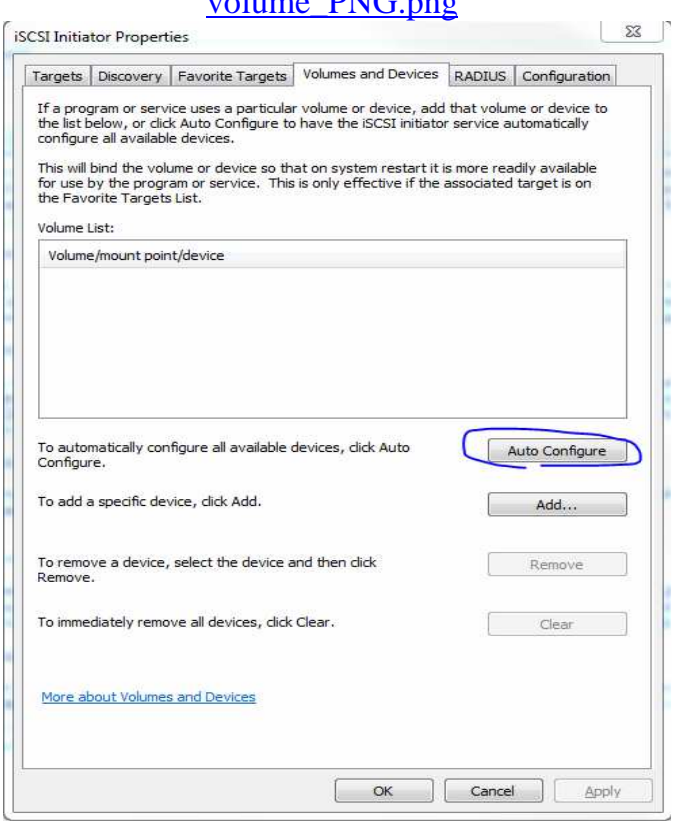

Рис. 9. Налаштування Autoconfigure

Після задання букв на першому гіпервізорі другий гіпервізор підключить імена дисків автоматично. У результаті отримано два гіпервізори, що мають по два загальних диски, які підключені через iSCSI до сховища. 


\section{Етап 4}

При налаштуванні кластера на двох наявних гіпервізорах майстер налаштування сам обирає файлові розділи під кворум та під дані. Як загальні ресурси були обрані диски, підключені по iSCSI, і як кворум був обраний найменший з них.

Після об'єднання двох гіпервізорів у кластер за допомогою майстра налаштування консоль кластера буде виглядати таким чином (рис. 10).

Для налаштування необхідно перейти на Cluster Shared Volumes - вкладку в консолі кластера. Саме на цьому сховищі можуть розміщатися віртуальні машини для забезпечення стабільної роботи шляхом перетворення звичайного кластерного ресурсу в shared, використовуючи кнопку «Add Storage» (рис. 11).

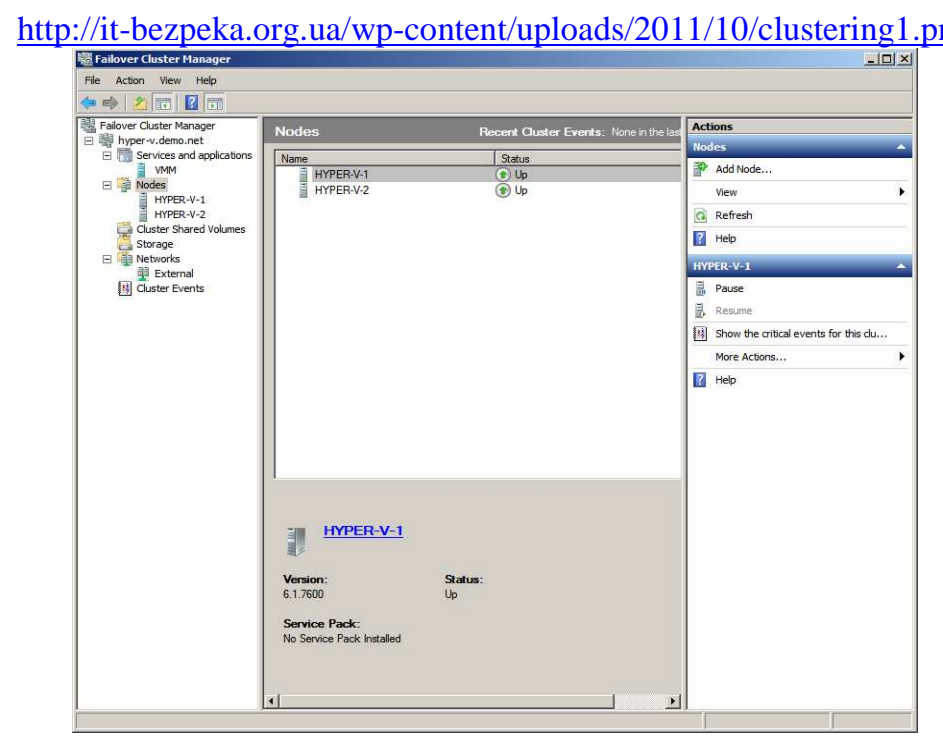

Рис. 10. Об'єднання двох гіпервізорів у кластер

http://it-bezpeka.org.ua/wp-content/uploads/2011/10/clustering2.png

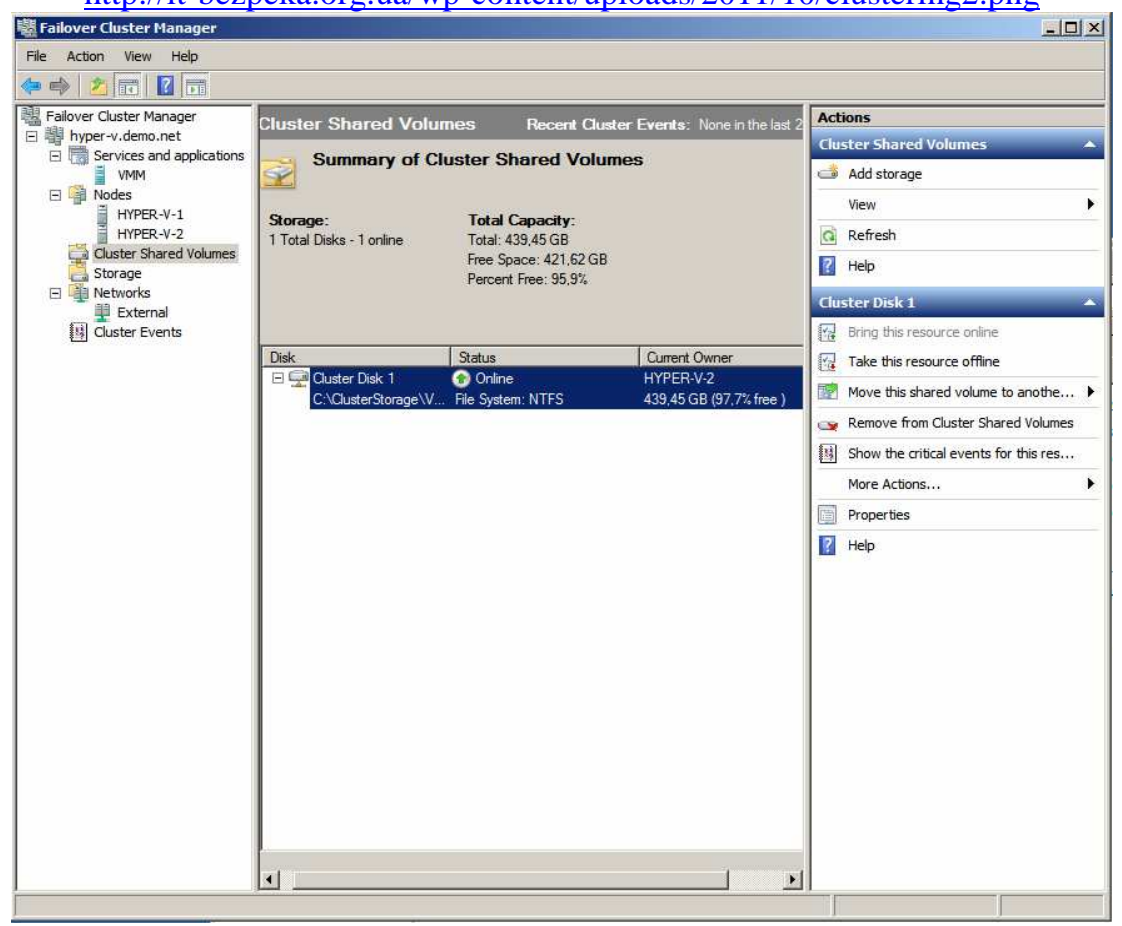

Рис. 11. Процедура перетворення кластерного ресурсу в shared 
Щоб уникнути зайвих проблем, при налаштуванні гіпервізорів на кожному вузлі треба вказати повні шляхи для дисків і віртуальних машин з розміщенням на загальному диску.
Етап 5

Створюються віртуальні машини безпосередньо на кластері шляхом вибору у вкладці сервісів Virtual Machines та вузла (рис. 12).

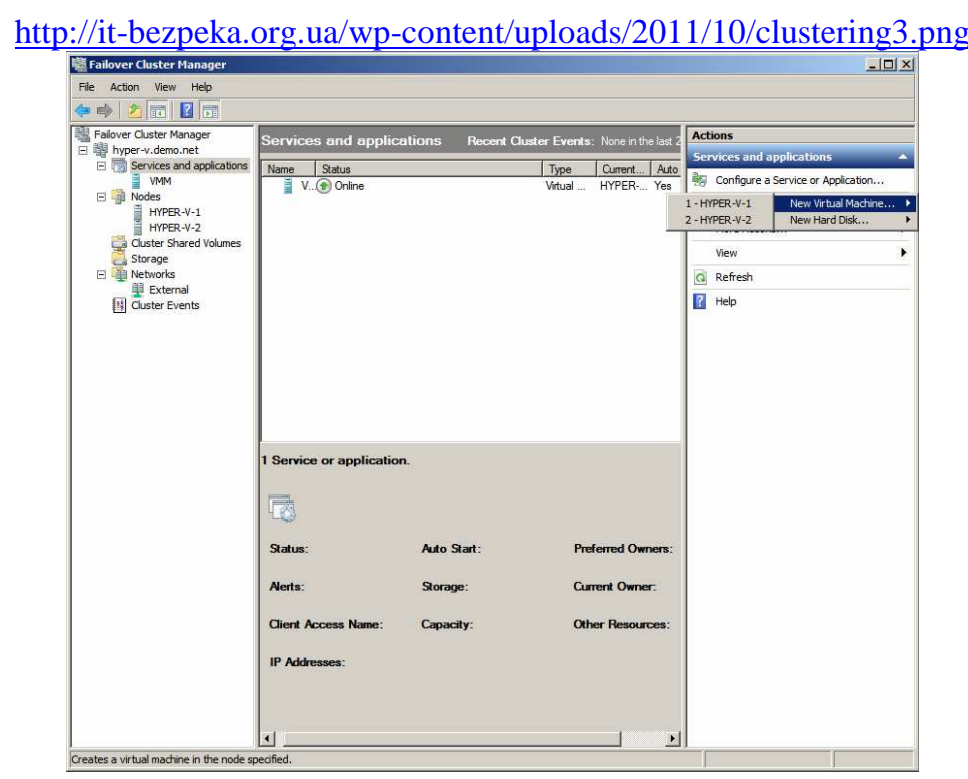

Рис. 12. Створення віртуальної машини

Далі монтується дистрибутив з ОС. Для коректної роботи Live Migration необхідна відсутність залежностей від зовнішніх ресурсів на кожному вузлі. Як дистрибутив використовується OC CentOS 5. При створенні віртуальної машини до неї додається мережний адаптер Legacy (рис. 13), який необхідний для відновлення CentOS та для установлення компонент інтеграції Hyper-V. Після цього треба запустити установку OC CentOS з дистрибутиву.

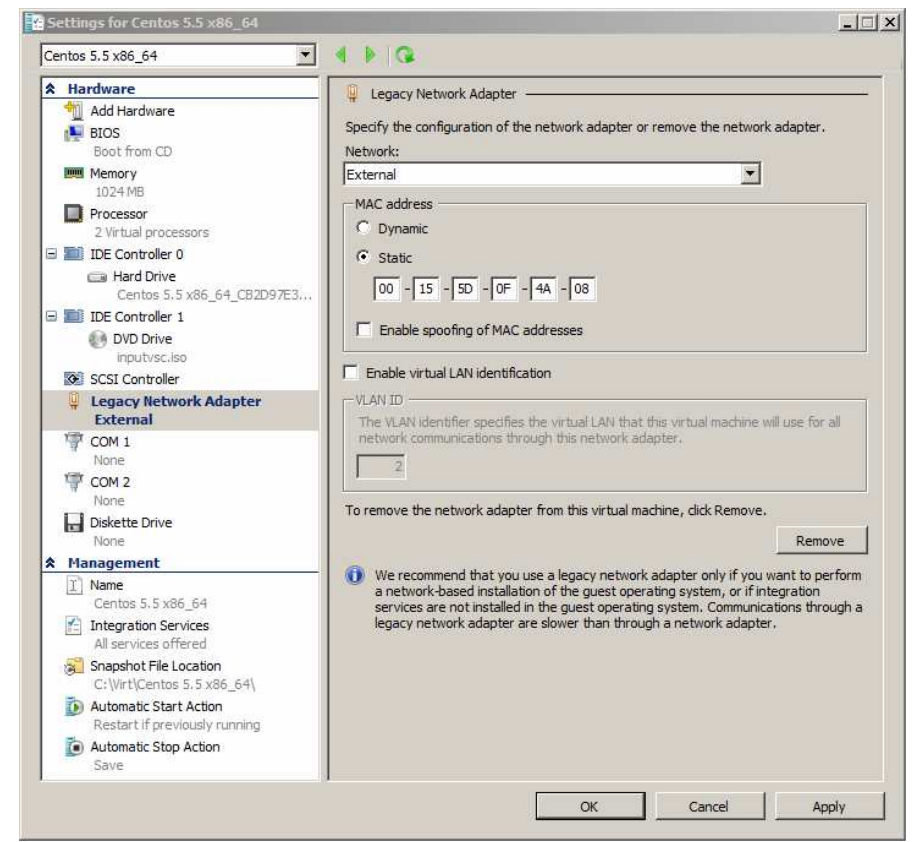

Рис. 13. Увімкнення мережного адаптера Legacy 
Для того, щоб сценарій тестування був найбільш ефективним, треба використовувати динамічні жорсткі диски VHD. Система досить ефективно працює 3 дисками розміром до 2 ТБ. Динамічні диски автоматично розширюються, що у разі необхідності допоможе розрахувати середню продуктивність дискових операцій (рис. 14).

Далі при установленні налаштовується мережний інтерфейс Legacy (рис. 15).

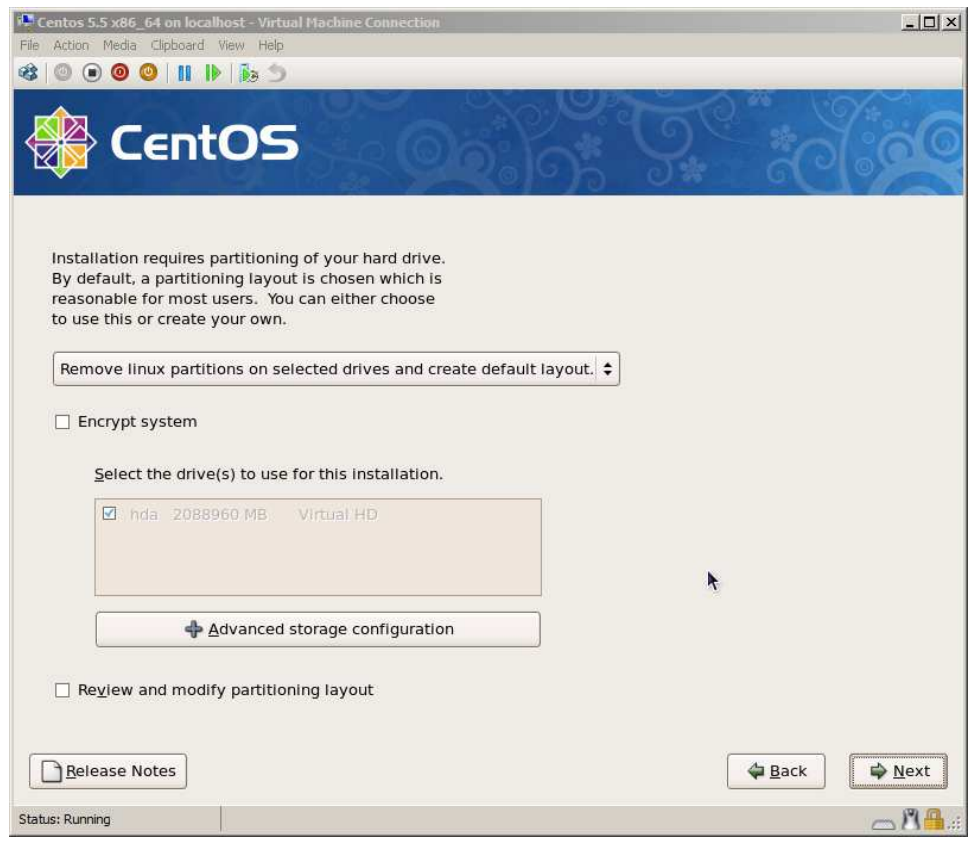

Рис. 14. Підключення динамічних дисків

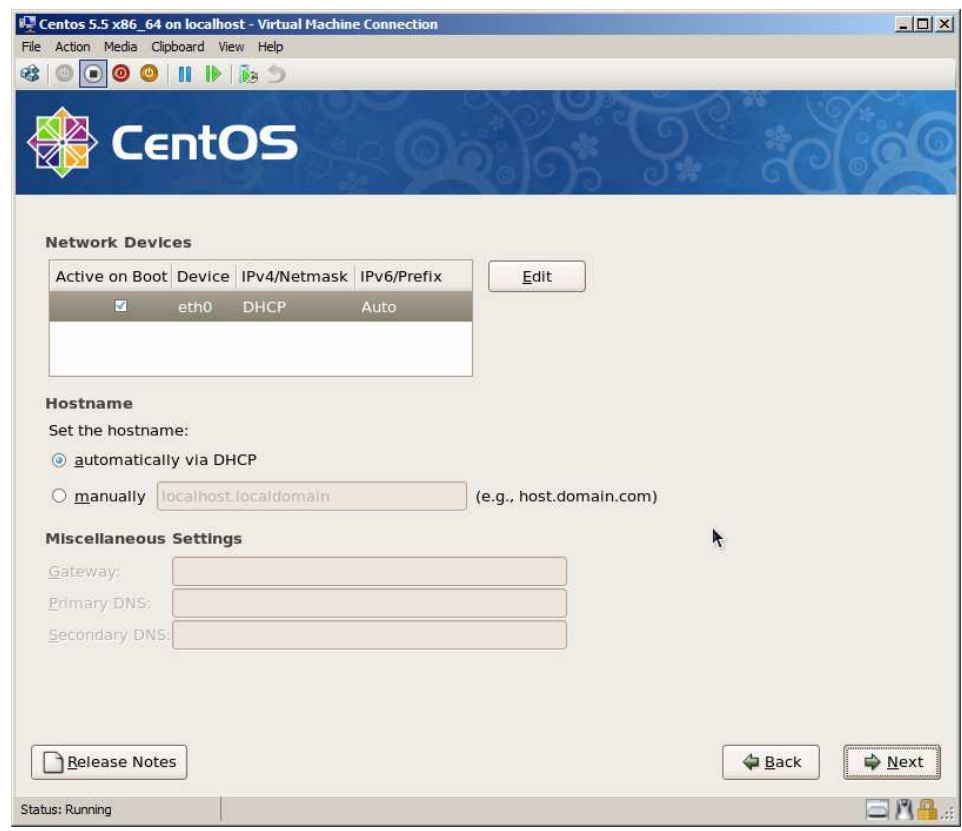

Рис. 15. Налаштування мережного інтерфейсу Legacy

Після цього установлення ОС виконується як на здійснюється вхід до гостьової системи та звичайному фізичному пристрої. Після завершення перевіряється робота комп'ютерної мережі (рис. 16, установлення та перезавантаження системи 17). 


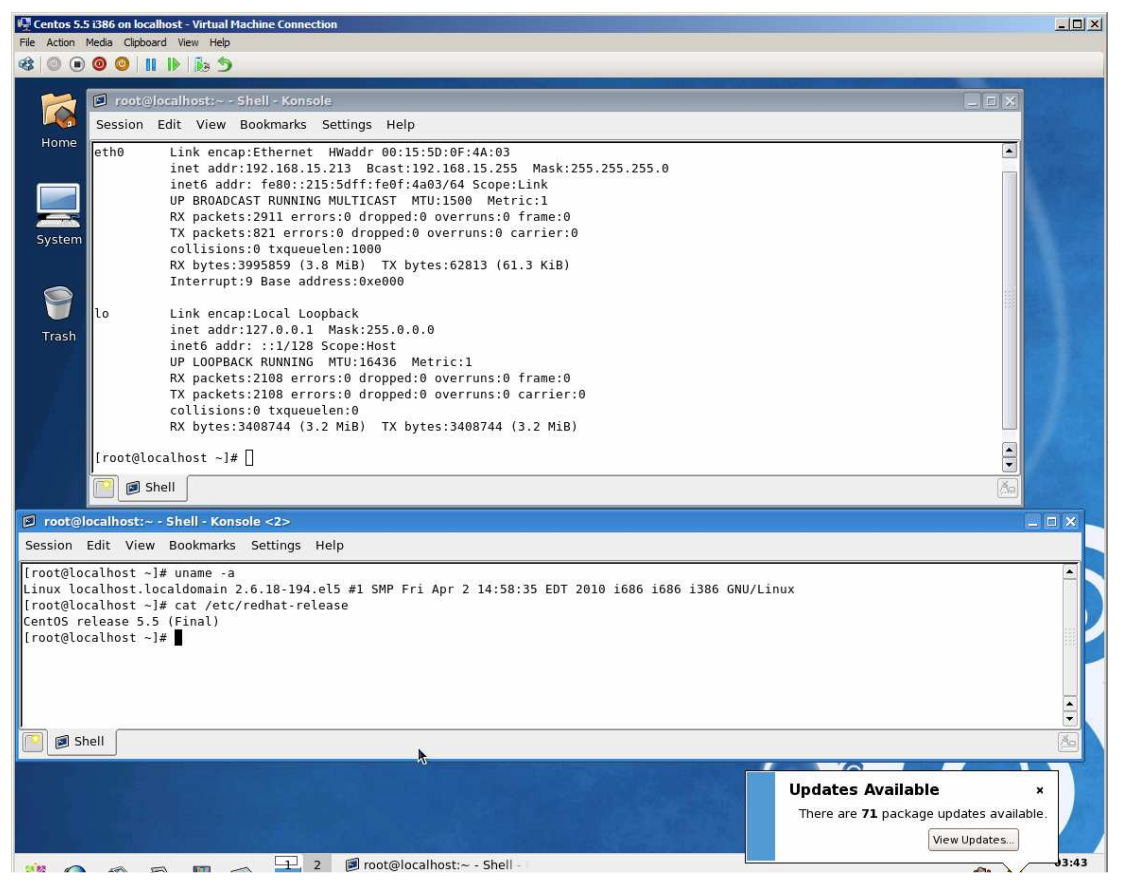

Рис. 16. Перевірка підключення

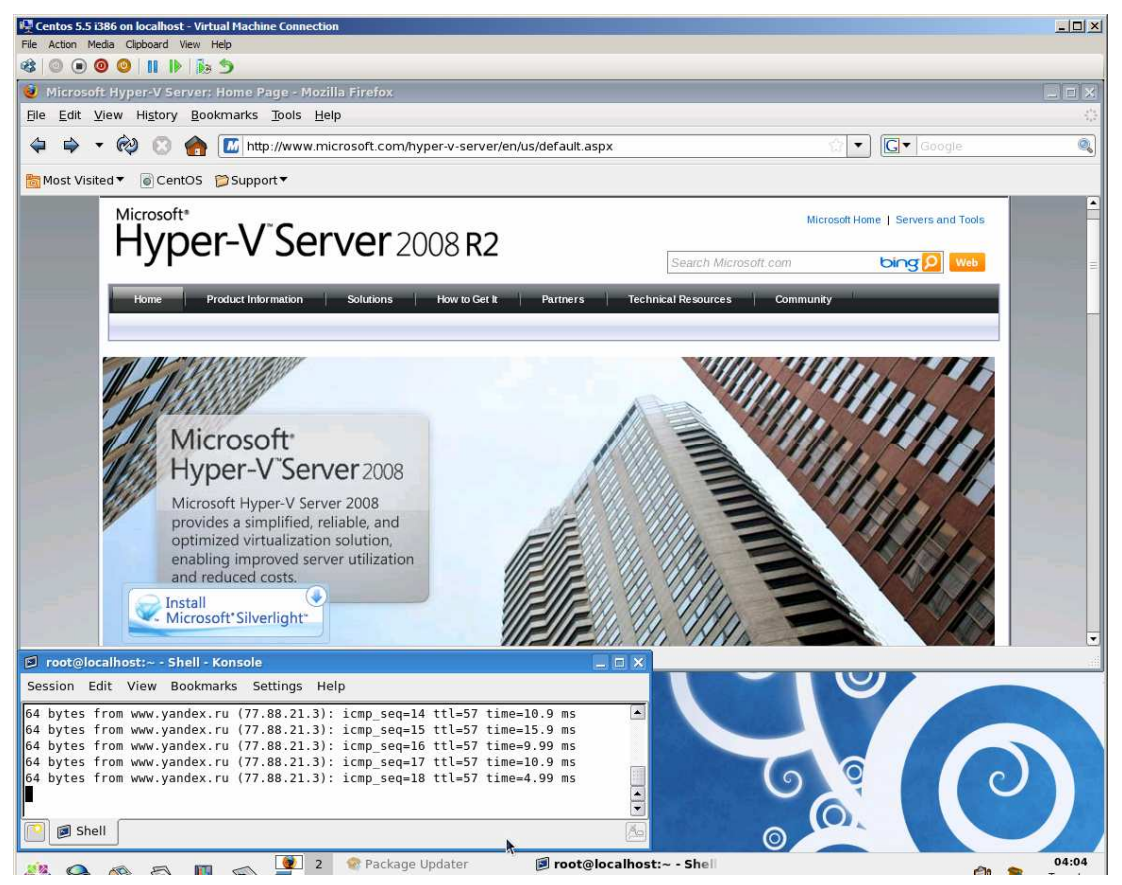

Рис. 17. Перевірка роботи комп'ютерної мережі

\section{Висновки}

Проаналізовані

характеристики

засобів віртуалізації при побудові обчислювальних кластерів дають змогу обрати найбільш продуктивні 3 них в певних умовах їх функціонування. Наведені процедури установлення та налаштування засобів віртуалізації обчислювального кластера дозволяють оцінити часові витрати та програмні засоби для налаштування та обслуговування цих технологій при експлуатації обчислювального кластера.

\section{Література}

1. Дудина, И. А. Разработка и реализация облачного планировщика, учитывающего топологию 
коммуникационной

среды

при

высокопроизводительных вычислениях [Текст] / И.А. Дудина, А.О. Кудрявцев, С.С. Гайсарян // Труды института системного программирования РАН. - 2013. - T. 24. - С. 35-48.

2. Листровой, С. В. Модель и подход к планированию распределения ресурсов в гетерогенных Грид-системах [Текст] / С.В. Листровой, С.В. Минухин // Проблемы управления и информатики: междунар. науч.-техн. журнал. - 2012. - № 5. - С. 120-133.

3 . http://linoxide.com/ubuntu-how-to/install-configureopenvz-ubuntu-14-04-15-04/.

4. OpenVZ [Електронний ресурс]. - Режим доступу: https://help.ubuntu.com/community/OpenVZ.

5. Установка OpenVZ на Ubuntu [Електронний pecypc]. - Режим доступу: http://linuxnotes.org/ustanovka-openvz-na-ubuntu/.

6. The Most Complete Virtualization Manager. Manage your entire server cluster from a single console. Free, Flexible and Open Source Режим доступу: http://lxcenter.org/software/hypervm.

7. Бесплатное ПО от Microsoft [Электронный ресурс]. - Режим доступа: https://www.microsoft.com/ruru/SoftMicrosoft/hyperv2012r2.aspx.

8. Режим

code.msdn.microsoft.com/HVRemote

9. Режим

доступу:

microsoft.com/systemcenter/virtualmachinemanager.

\section{Минухин С.В., Задачин В.М. Исследование средств создания вычислительного кластера на основе технологий виртуализации. Проведен анализ современных технологий создания вычислительных кластеров. Рассмотрены вопросы настройки и установки систем OpenVZ, HyperVM, Hyper-V. Рассмотрены этапы настройки OpenVZ для OC Ubuntu / Debian. Рассмотрены особенности настройки систем при решении задач виртуализации. Рассмотрены особенности НуреrVM как распространенной технологии для управления фермой физических и виртуальных серверов, используя веб- ориентированный интерфейс. Рассмотрены возможности использования НyperVM на основе управления сертификатами, протоколами удаленного доступа, определения списков сервисов и процессов и построения отчетов с работы виртуальных машин. Рассмотрены вопросы построения вычислительного кластера на основе операционной системы Linux на базе системы Hyper-V.}

Ключевые слова: виртуализация, операционная система, вычислительный кластер, сервер, виртуальная машина, компьютерная сеть.
Minukhin S.V., Zadachin V.M. The research of the creation of computer cluster based on virtualization technology. The analysis of modern technologies of computing clusters. The question of configuration and installation of OpenVZ, HyperVM, Hyper-V is considered. The stages of setting OpenVZ OS Ubuntu/Debian are developed. The features of setting in solving virtualization are considered. Features HyperVM a widespread technology for farm management of physical and virtual servers using webbased interface are considered. The possibilities of using HyperVM based management of certificates, remote access protocols, the definition lists services and processes and build reports of virtual machines are developed. The questions of building a computing cluster based on Linux operating system based on the system of Hyper- $\mathrm{V}$ are discussed. The features like Hyper- $\mathrm{V}$ virtual environment that runs on the hardware level are considered. The next stages of adjustment of virtualization environment are developed: hardware requirements are cconsidered that choose to use virtualization technologies to processor computing cluster system; Software included with the kernel and hypervisor management console for centralized control. The necessity of spending resources on the host server to support other roles to improve performance of virtualization technologies are developed. The stages of system settings, which include: setting up a computer network by identifying local servers for all IPaddresses prior to connection to the switch, permit remote access to the cluster nodes using RDP and console MM, determination node domain, domain definitions and connect it to the cluster nodes; configuration repository to store virtual machines; virtual machines directly to the cluster; mounting distribution to work correctly with no dependencies on external resources on the nodes of a computer network operating system CentOS.

Key words: virtualization, operating system, computer cluster, server, virtual machine, computer network.

Рецензент д.т.н., професор Лістровий С.В. (УкрДУЗТ)

Надійшла 18.04.2016 p.

Мінухін Серхій Володимирович, кандидат технічних наук, дочент, професор кафедри інформаційних систем Харківського національного економічного університету імені Семена Кузнеия. E-mail: minukhin.sv@gmail.com.

Задачин Віктор Михайлович, кандидат фізикоматематичних наук, доцент, доцент кафедри інформаційних систем Харківського наџіонального економічного університету імені Семена Кузнечя. E-mail: zadachinvm@gmail.com.

Minukhin Sergii Vladimirovich, candidate of technical sciences, professor of information systems department, Simon Kuznets Kharkiv National University of Economics.

Zadachin Victor Mikhailovich, Candidate of Physical and Mathematical Sciences, Associate Professor of information systems department, Simon Kuznets Kharkiv National University of Economics. 